\title{
PENGARUH PENGGUNAAN TAHU SEBAGAI EXTENDER TERHADAP SIFAT ORGANOLEPTIK SOSIS AYAM
}

\author{
Sakina Ningsi, John E. G. Rompis*, E. H. B. Sondakh, Nova Lontaan \\ Fakultas Peternakan Universitas Sam Ratulangi Manado 95115
}

\begin{abstract}
ABSTRAK
Tujuan penelitian ini untuk mengetahui pengaruh penggunaan tahu sebagai extender terhadap sifat organoleptik sosis ayam. Bahan yang digunakan adalah daging broiler (bagian dada), tahu, dan bahan pembentuk sosis lainnya. Lima perlakuan yang diuji dalam penelitian ini terdiri dari T0 daging $500 \mathrm{~g}$ tanpa tahu, T1 daging $475 \mathrm{~g}$ ditambah tahu $25 \mathrm{~g}$, T2 daging $450 \mathrm{~g}$ ditambah tahu $50 \mathrm{~g}$, T3 daging $425 \mathrm{~g}$ ditambah tahu $75 \mathrm{~g}$ dan T4 daging 400 gram ditambah tahu $100 \mathrm{~g}$. Percobaan ini menggunakan rancangan acak lengkap dan dinilai oleh 35 orang panelis untuk menentukan sifat organoleptic dari produk sosis ayam. pengukuran data organoleptik menggunakan skala hedonik yang terdiri dari variable-variabel warna, aroma, tekstur dan citarasa. Untuk menentukan perbedaan perlakuan dilakukan dengan uji BNJ. Hasil penelitian menunjukkan bahwa perlakuan memberikan pengaruh sangat nyata $(\mathrm{P}<$ 0,01) terhadap warna, aroma, tekstur, citarasa sosis ayam, Kesimpulannya adalah berdasarkan sifat organoleptik, penggunaan tahu 25 gram sebagai bahan extender pada 475 gram daging dapat digunakan dalam pembuatan sosis ayam.
\end{abstract}

Kata kunci: Sosis Ayam, Tahu, Organoleptik

*Korespondensi (corresponding author)

Email: jegronne@yahoo.co.id
ABSTRACT

THE USE OF TOFU AS EXTENDER ON ORGANOLEPTIC CHARACTERISTIC OF CHICKEN SAUSAGE. This study was conducted to know about the use of tofu as an extender to sausage product of broiler on the organoleptic characteristics. The material used in this study were broiler meat (breast chicken), tofu and the ingredients for sausage making. Five treatments tested in this research consisted of T0 $500 \mathrm{~g}$ of meat without tofu, T1 $475 \mathrm{~g}$ of meat and tofu 25 $\mathrm{g}, \mathrm{T} 2450 \mathrm{~g}$ of meat and tofu $50 \mathrm{~g}, \mathrm{~T} 3425 \mathrm{~g}$ of meat and tofu $75 \mathrm{~g}$, T4 $100 \mathrm{~g}$ of meat and tofu $100 \mathrm{~g}$. This research used complete randomized design and was tested by 35 of panelist to determine organoleptic data of sausage product. The data measured in this research used hedonic scale. The variable measured consisted of color, flavor, texture, taste of sausages. Determination of the difference of average was done by BNJ test. The result showed that the treatment was significant effect on color, flavor, texture, taste of sausage. The conclusion of this study based on organoleptic characteristics, The use of $25 \mathrm{~g}$ tofu as extender ingredient to $475 \mathrm{~g}$ of meat can be used on making chicken sausage.

Keywords: Sausages, Chicken, Tofu, Organoletic 


\section{PENDAHULUAN}

Daging ayam sebagai komoditas peternakan sangat dibutuhkan untuk pemenuhan protein hewani, karena mampu untuk memenuhi zat gizi yang dibutuhkan oleh tubuh (Suradi, 2006 dan Montolalu, 2013). Komposisi daging ayam terdiri dari protein $18,6 \%$; lemak $15,0 \%$; air $65,95 \%$ dan abu 0,79\% (Suradi, 2006). Daging olahan adalah daging yang digiling dan dibentuk kembali (restrukturisasi) diperoleh dari hasil pengolahan dengan bahan tambahan menjadi produk olahan daging yang siap saji seperti sosis (Prayitno et al., 2009). Produk daging olahan didefinisikan sebagai modifikasi sifat-sifat daging segar melalui satu atau lebih prosedur, seperti penggilingan, pencacahan (chopping) dan penambahan penyedap rasa, serta perlakuan panas. Sosis daging ayam merupakan produk olahan yang dapat dikonsumsi oleh berbagai usia dan banyak disukai oleh konsumen, karena memiliki kandungan protein tinggi $13 \%$ dan harga yang terjangkau (Lawrie, 2003). Dalam pembuatan sosis daging ayam terdapat berbagai macam bahan yang digunakan salah satunya bahan extender. Bahan extender merupakan bahan selain daging yang ditambahkan, yang dapat berupa bahan pengisi, bahan pengikat dan pengemulsi atau penstabil (Herlina et al., 2012). Tahu merupakan salah satu produk olahan kacang kedelai, yang paling banyak dan paling popular di Indonesia untuk dikonsumsi. Menurut Widaningrum (2015) tahu mengandung protein nabati dan mempunyai kualitas terbaik karena memiliki komposisi asam amino paling lengkap serta memiliki daya cerna yang tinggi (sebesar 85\%-98\%).

Penilaian organoleptik adalah penilaian mutu suatu produk dengan menggunakan indera manusia melalui syaraf sensorik meliputi sifat yang dapat dilihat, diraba, dicium dan dirasa. Analisis sifat organoleptik dapat membantu pendugaan parameter untuk formula baru, sedangkan pengukuran menggunakan alat (instrument) dibutuhkan untuk menyakinkan konsistensi kualitas suatu produk (Soekarto dan Hubeis, 1992). Mutu hedonik, yang biasanya dikaitkan dengan potensi penerimaan produk oleh konsumen. Berdasarkan permasalahan diatas maka dilakukan penetian tentang pengaruh penggunaan tahu sebagai extender terhadap sifat organoleptik sosis ayam.

\section{MATERI DAN METODE PENELITIAN}

\section{Waktu dan Tempat Penelitian}

Penelitian ini telah dilaksanakan di Laboratorium Teknologi Hasil Ternak Fakultas Peternakan Universitas Sam 
Ratulangi Manado, pada tanggal 5 Januari sampai 20 Januari 2017.

\section{Materi Penelitian}

Bahan. Bahan utama yang digunakan dalam penelitian ini adalah daging broiler bagian dada sebanyak 2250 gram, tahu sebanyak 250 gram, bawang putih, pala, lada, cengkeh, minyak, garam, jahe, tepung tapioka, gula, es batu. Komposisi bahan penyusun sosis yang digunakan pada penelitian ini dapat dilihat pada Tabel 1.

Alat. Peralatan yang digunakan untuk pembuatan sosis terdiri atas alat penggiling, timbangan (ELECTRONIC BALANCE Ser. No. 2906467) untuk menimbang bahan-bahan yang akan digunakan, blender untuk menghaluskan cengkeh, pala, jahe, water bath (Thermologic BW 81 seri nomor 8603036) untuk mengukus sosis, termometer untuk mengukur suhu, selongsong berdiameter 2,2 $\mathrm{mm}$ panjang $10 \mathrm{~cm}$, benang katun nomor 8 , gunting, pisau, timbangan digital, wadah plastik, alat tulis menulis dan peralatan penunjang lainnya.

\section{Metode Penelitian}

Rancangan percobaan yang digunakan dalam penelitian ini adalah Rancangan Acak Lengkap (RAL) ( Steel and Torrie 1991). Data yang diperoleh dianalisis dengan ANOVA yang terdiri dari 5 perlakuan dan 35 orang panelis sebagai ulangan. Penelitian ini menggunakan uji mutu hedonik. Apabila terdapat perbedaan antar perlakuan dilakukan uji BNJ.

Tabel 1. Komposisi Bahan Penyusun Sosis Ayam

\begin{tabular}{lccccc}
\hline \multirow{2}{*}{ Bahan (gram) } & \multicolumn{5}{c}{ Perlakuan } \\
\cline { 2 - 6 } & $\mathrm{T}_{0}$ & $\mathrm{~T}_{1}$ & $\mathrm{~T}_{2}$ & $\mathrm{~T}_{3}$ & $\mathrm{~T}_{4}$ \\
\hline Daging & 500 & 475 & 450 & 425 & 400 \\
Tahu & 0 & 25 & 50 & 75 & 100 \\
Bawang putih & 2,5 & 2,5 & 2,5 & 2,5 & 2,5 \\
Lada & 1 & 1 & 1 & 1 & 1 \\
Garam & 15 & 15 & 15 & 15 & 15 \\
Gula & 0,75 & 0,75 & 0,75 & 0,75 & 0,75 \\
Pala & 0,25 & 0,25 & 0,25 & 0,25 & 0,25 \\
Tepung tapioka & 17,5 & 17,5 & 17,5 & 17,5 & 17,5 \\
Minyak nabati & 25 & 25 & 25 & 25 & 25 \\
Jahe & 0,25 & 0,25 & 0,25 & 0,25 & 0,25 \\
Cengkeh & 0,25 & 0,25 & 0,25 & 0,25 & 0,25 \\
Es batu & 125 & 125 & 125 & 125 & 125 \\
\hline
\end{tabular}




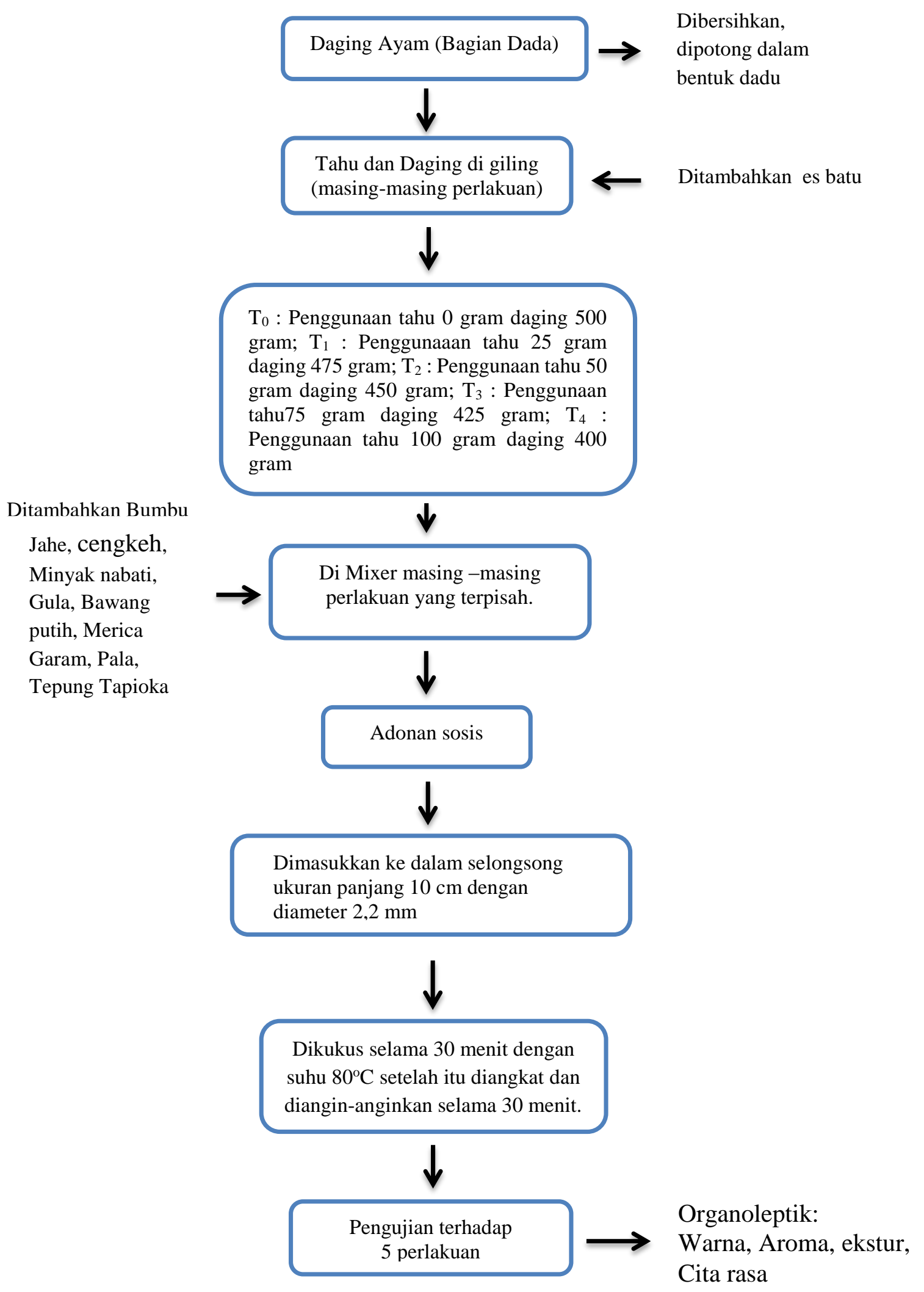

Gambar 1. Diagram Pembuatan Sosis 


\section{Variabel Yang Diamati}

Variabel yang diamati adalah sifat organoleptik sosis ayam yaitu warna, aroma, tekstur, citarasa yang disajikan menggunakan format uji. Penelitian ini menggunakan uji organoleptik dengan skala hedonik 1 sampai 7, panelis yang digunakan adalah panelis tidak terlatih sebanyak 35 orang (Rahayu, 2001).

\section{HASIL DAN PEMBAHASAN}

Uji mutu organoleptik terhadap suatu bahan pangan merupakan indikator yang dapat menunjukkan tingkat penerimaan konsumen terhadap produk tersebut. Pengaruh penggunaan tahu sebagai extender terhadap sifat organoleptik sosis ayam yang diamati dalam penelitian ini yakni; warna, aroma, tekstur, citarasa, dapat dilihat pada Tabel 2.

\section{Warna Sosis Ayam}

Hasil pengamatan untuk penggunaan tahu sebagai extender terhadap warna sosis ayam dapat dilihat pada Tabel 2. Data tersebut menunjukkan bahwa nilai warna sosis berada pada kisaran rataan 3,37 (agak tidak menarik) pada perlakuan T4 sampai 6,37 (menarik) pada perlakuan T0. Rataan skor tertinggi yang diberikan panelis terhadap warna sosis ayam berada pada perlakuan dengan komposisi daging $500 \mathrm{~g}$ dan tahu $0 \mathrm{~g}$ (T0) yaitu 6,37 kemudian skor terendah pada penggunaan tahu $100 \mathrm{~g}$ (T4) yakni 3,37.

Hasil analisis sidik ragam menunjukkan bahwa pengaruh penggunaan tahu sebagai extender pada sosis ayam berpengaruh sangat nyata $(\mathrm{P}<0,01)$ terhadap warna sosis. Uji lanjut dengan menggunakan BNJ menunjukkan bahwa perlakuan penggunaan tahu memberikan perbedaan warna untuk setiap perlakuan $(\mathrm{P}<0,05)$ kecuali pada perlakuan T0 dan T1 menunjukkan warna yang sama $(\mathrm{P}>0,05)$.

Perbedaan warna yang diberikan oleh panelis menunjukkan terjadi penurunan tingkat kesukaan terhadap warna sosis ayam dengan penggunaan tahu sebagai extender. Panelis lebih menyukai sosis tanpa tahu atau penggunaan tahu yang lebih sedikit. Penggunaan tahu mempengaruhi warna sosis ayam, semakin tinggi penggunaan tahu menyebabkan warna sosis berubah menjadi warna agak putih. Panelis lebih menyukai sosis yang berwarna seperti warna daging. Menurut Anggraeni et al. (2014), warna dari produk olahan daging sosis adalah warna merah kecoklatan. Menurut Soeparno (1994) warna pada sosis dapat berasal dari bahan utamanya yaitu daging, bahan pengisi dan bahan pengikat serta bahan-bahan yang ditambahkan. Sidik (2003) menyatakan bahwa penggunaan tepung yang berbeda memungkinkan produk sosis memiliki warna yang berbeda 
Tabel 2. Nilai Rataan Pengaruh Penggunaan Tahu Sebagai Extender Terhadap Sifat Organoletik Sosis Ayam

\begin{tabular}{lccccc}
\hline & \multicolumn{5}{c}{ Perlakuan Penggunaan Daging/Tahu (gram) } \\
\cline { 2 - 6 } Variabel & T0 & T1 & T2 & T3 & T4 \\
& $500 / 0$ & $475 / 25$ & $450 / 50$ & $425 / 75$ & $400 / 100$ \\
\hline Warna & $6,37^{\mathrm{a}} \pm 0,55$ & $5,91^{\mathrm{a}} \pm 0,74$ & $4,83^{\mathrm{b}} \pm 0,66$ & $4,06^{\mathrm{c}} \pm 0,68$ & $3,37^{\mathrm{d}} \pm 0,94$ \\
Aroma & $6,11^{\mathrm{a}} \pm 0,63$ & $5,49^{\mathrm{b}} \pm 0,56$ & $4,66^{\mathrm{c}} \pm 0,59$ & $4,03^{\mathrm{d}} \pm 0,62$ & $3,14^{\mathrm{e}} \pm 0,60$ \\
Tekstur & $6,14^{\mathrm{a}} \pm 0,69$ & $5,71^{\mathrm{a}} \pm 0,46$ & $4,86^{\mathrm{b}} \pm 0,69$ & $4,03^{\mathrm{c}} \pm 0,82$ & $3,23^{\mathrm{d}} \pm 0,81$ \\
Citarasa & $6,49^{\mathrm{a}} \pm 0,51$ & $5,49^{\mathrm{b}} \pm 0,70$ & $4,69^{\mathrm{c}} \pm 0,63$ & $4,11^{\mathrm{d}} \pm 0,72$ & $3,31^{\mathrm{e}} \pm 0,68$ \\
\hline
\end{tabular}

Keterangan : Superskrip berbeda pada baris yang sama artinya berbeda nyata $(\mathrm{P}<0,05)$

Warna mempengaruhi penerimaan suatu bahan pangan, sebab warna yang menarik akan meningkatkan tingkat kesukaan konsumen.

\section{Aroma Sosis Ayam}

Hasil pengamatan untuk penggunaan tahu sebagai extender terhadap aroma sosis ayam dapat dilihat pada Tabel 2. Data tersebut menunjukkan bahwa nilai aroma sosis berada pada kisaran rataan skor 3,14 (agak tidak suka) pada perlakuan T4 sampai skor 6,11 (suka) pada perlakuan T0. Rataan skor tertinggi yang diberikan panelis terhadap aroma sosis ayam berada pada perlakuan T0 dengan komposisi daging $500 \mathrm{~g}$ dan tahu $0 \mathrm{~g}$ dan skor terendah pada perlakuan T4 dengan komposisi daging $400 \mathrm{~g}$ dan tahu $100 \mathrm{~g}$.

Hasil analisis sidik ragam menunjukkan bahwa penggunaan tahu sebagai extender pada sosis ayam berpengaruh sangat nyata $(\mathrm{P}<0,01)$ terhadap aroma sosis. Uji lanjut dengan menggunakan BNJ terhadap aroma sosis ayam menunjukkan bahwa terdapat perbedaan aroma sosis untuk setiap perlakuan.

Perbedaan aroma yang diberikan oleh panelis menunjukkan terjadi penurunan tingkat kesukaan panelis terhadap aroma sosis ayam dengan penggunaan tahu sebagai extender. Semakin banyak penambahan tahu maka aroma daging pada sosis akan berkurang sebaliknya aroma tahu semakin meningkat. Penilaian aroma sosis oleh panelis diduga lebih dititik beratkan pada kesesuaian aroma daging pada produk sosis tersebut. Menurut Widjanarko et al. (2012) Aroma produk olahan sosis yang disukai adalah aroma daging. Hasil penelitian ini sejalan dengan pendapat dari Rauf et al. (2015) yang menyatakan bahwa aroma produk olahan daging dapat dipengaruhi oleh bahan-bahan yang ditambahkan selama pembuatan dan pemasakan produk olahan daging. Pada penelitian ini seluruh bahan yang 
ditambahkan selain daging dan tahu mempunyai nilai komposisi yang sama.

\section{Tekstur Sosis Ayam}

Hasil pengamatan untuk penggunaan tahu sebagai extender terhadap tekstur sosis ayam dapat dilihat pada Tabel 2. Data tersebut menunjukkan bahwa nilai tekstur sosis berada pada kisaran skor rataan 3,23 (agak kasar) pada perlakuan T4 sampai skor rataan 6,14 (halus) pada perlakuan T0. Rataan skor tertinggi yang diberikan panelis terhadap tekstur sosis ayam berada pada perlakuan dengan komposisi daging $500 \mathrm{~g}$ dan tahu $0 \mathrm{~g}$ pada perlakuan T0 yaitu 6,14 dan skor terendah pada perlakuan T4 dengan komposisi daging $400 \mathrm{~g}$ dan tahu $100 \mathrm{~g}$.

Hasil analisis sidik ragam menunjukkan bahwa pengaruh penggunaan tahu sebagai extender terhadap sifat organoleptik sosis ayam berpengaruh sangat nyata $(\mathrm{P}<0,01)$ terhadap tekstur daging. Uji lanjut dengan menggunakan BNJ menunjukkan bahwa perlakuan penggunaan tahu memberikan perbedaan tekstur sosis untuk setiap perlakuan $(\mathrm{P}<0,05)$ kecuali pada perlakuan $\mathrm{T} 0$ dan $\mathrm{T} 1$ menunjukkan tekstur sosis yang sama $(\mathrm{P}>0,05)$.

Perbedaan tekstur yang diberikan oleh panelis menunjukkan terjadi penurunan tingkat kesukaan panelis terhadap tekstur sosis ayam dengan penggunaan tahu sebagai extender. Semakin banyak bahan extender tahu pada produk sosis semakin menurun tingkat kesukaan terhadap tekstur sosis. Penurunan tingkat kesukaan terhadap tekstur sosis seiring dengan penambahan tahu untuk setiap perlakuan. Menurut Putri dan Yuwono (2016), tekstur tahu yang dihasilkan dapat dipengaruhi oleh penurunan $\mathrm{pH}$ yang selama proses koagulasi, sehingga penggunaan jenis koagulan sangat mempengaruhi tekstur tahu yang dihasilkan. Menurut RuizCapillas et al. (2012), tekstur juga ditentukan oleh komposisi bahan penyusun sosis, kondisi homogenisasi dan proses pengolahannya. Produk olahan sosis ayam memiliki tekstur lembut dan halus (Lukman, 2015).

\section{Citarasa Sosis Ayam}

Hasil pengamatan penggunaan tahu sebagai extender terhadap citarasa sosis ayam dapat dilihat pada Tabel 2. Data tersebut menunjukkan citarasa sosis berada pada kisaran rataan 3,31 (agak tidak enak) terdapat pada perlakuan T4 sampai 6,49 (enak) pada perlakuan T0. Rataan skor tertinggi yang diberikan panelis terhadap citarasa sosis ayam berada pada perlakuan T0 dengan komposisi daging $500 \mathrm{~g}$ dan tahu $0 \mathrm{~g}$ dan skor terendah pada perlakuan $\mathrm{T} 4$ dengan komposisi daging $400 \mathrm{~g}$ dan 
tahu 100 g. Hasil analisis sidik ragam menunjukkan bahwa pengaruh penggunaan tahu sebagai extender terhadap sifat organoleptik sosis ayam berpengaruh sangat nyata $(\mathrm{P}<0,01)$ terhadap citarasa daging. Uji lanjut dengan menggunakan BNJ terhadap citarasa sosis ayam menunjukkan bahwa terdapat perbedaan aroma sosis untuk setiap perlakuan.

Perbedaan citarasa yang diberikan oleh panelis dalam artian terjadi penurunan tingkat kesukaan citarasa sosis ayam seiring dengan penambahan tahu sebagai bahan ekstender. Semakin banyak penggunaan tahu maka tingkat kesukaan terhadap citarasa sosis ayam menurun. Panelis lebih condong memberikan penilaian citarasa terhadap produk olahan yang banyak mengandung daging. Menurut Purnawati et al. (2015) Konsumen lebih menyukai produk olahan dengan rasa daging. Prayitno (2009) menyatakan bahwa rasa suatu bahan pangan dapat berasal dari bahan pangan itu sendiri dan bahan lain pada produk yang ditambahkan.

\section{KESIMPULAN}

Berdasarkan sifat organoleptik, penggunaan tahu 25 gram sebagai bahan extender pada 475 gram daging dapat digunakan dalam pembuatan sosis ayam.

\section{DAFTAR PUSTAKA}

Aggraeni, D. A., S. B. Widjanarko dan D. W. Ningtyas. 2014. Proporsi tepung porang (Amorphophallus muelleri Blume): tepung maizena terhadap karakteristik sosis ayam. Jurnal Pangan dan Agroindustri 2(3): 214223

Herlina, Palupi W. N, A. N. B. Rusmana, 2012. Karakterisasi sosis daging ayam yang dibuat dengan penambahan tepung komposit tapioka dan gembolo sebagai bahan pengisi. Agrotek. J. 6(1): 99-111

Lawrie, R. A. 2003. Ilmu Daging. Terjemahan A. Parakkasi. Universitas Indonesia Press, Jakarta

Lukman, H. 2015. Alternatif angkak sebagai bahan tambahan pangan alami terhadap karakteristik sosis daging ayam. Fakultas Peternakan Universitas Jambi. Jurnal Ilmu-Ilmu Peternakan. 18(2)

Montolalu, S. 2013. Sifat fisiko - kimia dan mutu organoleptik bakso broiler dengan menggunakan tepung ubi jalar (Ipomoea batatas L) Jurnal Zootek 32(5)

Prayitno, A.H., F. Miskiyah, A.V. Rachmawati, T.M. Baghaskoro, B.P. Gunawan dan Soeparno. 2009. Karakteristik $\beta$-Caroten dari labu kuning (Curcubita moschata). Buletin Peternakan 33(2): 111-118.

Purnawati, T. R., Y. Praptiningsih dan Sukatiningsih. 2015. Karakteristik sensoris dan fisiokimia sosis lele dumbo (Clarias gariepinus) yang dibuat dengan variasi jenis dan konsentrasi bahan pengikat. Fakultas Teknologi Pertanian, Universitas Jember. Jurnal Berkala Ilmiah Pertanian 10 (10): 
Putri, A.D. dan S. S. Yuwono. 2016 Pengaruh penambahan tepung ampas tahu dan jenis koagulan pada pembuatan tahu berserat. Jurnal Pangan dan Agroindustri 4(1):321328

Rahayu, W.P. 2001. Penuntun Praktikum Penilaian Organoleptik. Jurusan Teknologi Pangan dan Gizi. Fakultas Teknologi Pertanian. IPB. Bogor.

Rauf, N.H, R.S. Sulistijowati, R.M. Harmain. 2015 mutu organoleptik sosis lele yang disubtitusi dengan rumput laut. Jurnal Ilmiah Perikanan dan Kelautan 3(3): 125- 129

Ruiz-Capillas, C., M. Triki, A.M. Herrero, L. Rodriguez-Salas, dan F. JimenezColmenero. 2012. Konjac gel as pork backfat replacer in dry fermented sausages: Processing and quality characteristics. Meat Science Jurnal 92(2): 144-150

Steel, R.G.D dan J.H. Torrie. 1991. Prinsip Dan Prosedur Statistika. Penerjemah Bambang Sumantri. Gramedia Pustaka Jakarta.
Soekarto, T. S. dan N. Hubeis, 1992. Petunjuk Menggunakan Laboratorium Metode Penelitian Indrawi. Pusat Antar Universitas Pangan dan Gizi. IPB. Bogor.

Soeparno. 1994. Ilmu dan Teknologi Daging. Penerbit Universitas Gadjah Mada, Yogyakarta.

Sidik, W. D. 2003. Pengaruh substitusi jamur tiram putih dan jenis pati terhadap kualitas bakso sapi dengan isian saus. Jurnal Teknologi dan Industri Pangan. 2(2): 63-72

Widiastuti Thahjani. 2016. Manajemen Pemasaran Produk Unggas Dengan rantai Dingin. Seminar ISPI. Direktorat Jenderal Peternakan dan Kesehatan Hewan. Kementerian Pertanian. Jakarta

Widjanarko, B. S., E. Zubaidah dan A. M. Kusuma. 2012. studi kualitas fisikkimiawi dan organoleptik sosis ikan lele dumbo (Clarias gariepinus) akibat pengaruh perebusan, pengukusan dan kombinasinya dengan pengasapan. Jurusan Teknologi Hasil Pertanian, FTP Unibraw. J. Tek. Pert. 4(3): 193-202 